\title{
Effects of geogrid encasement on lateral and vertical deformations of stone columns in model tests
}

\author{
M. Gu${ }^{1}$, M. Zhao ${ }^{2}$, L. Zhang ${ }^{3}$ and J. $\operatorname{Han}^{4}$ \\ ${ }^{1}$ PhD Student, College of Civil Engineering, Hunan University, Changsha, China 410082, \\ Telephone: +1 785840 5286; Telefax: +86 7318882 2667; E-mail: gmxhnu@gmail.com \\ Currently visiting scholar, Department of Civil, Environmental, and Architectural Engineering, \\ The University of Kansas, 2150 Learned Hall, 15th Street, Lawrence, KS 66045, USA \\ ${ }^{2}$ Professor, College of Civil Engineering, Hunan University, Changsha, China 410082, \\ Telephone: +86 7318882 1590; Telefax: +86 7318882 2667; E-mail: mhzhaohd@21cn.com \\ (corresponding author) \\ ${ }^{3}$ Research Associate, College of Civil Engineering, Hunan University, Changsha, China 410082, \\ Telephone: +86 7318882 1659; Telefax: +86 7318882 2667; E-mail: zhanglhd@yahoo.com \\ ${ }^{4}$ Professor, Department of Civil, Environmental, and Architectural Engineering, The University of Kansas, \\ 2150 Learned Hall, 15th Street, Lawrence, KS 66045, USA, Telephone: +1 785864 3714; \\ Telefax: +1 785864 5631; E-mail: jiehan@ku.edu
}

Received 11 February 2015, revised 13 July 2015, accepted 5 August 2015, published 5 October 2015

\begin{abstract}
Geosynthetic encasement of individual stone columns can provide additional confinement to the columns thus increasing their load capacities and reducing lateral and vertical deformations. Most of past studies have been focused on the load capacities and settlements (i.e. vertical deformations) of the encased stone columns. However, the load transfer mechanism and the lateral bulging deformation pattern of the encased stone columns are not thoroughly understood. In the present study, four series of laboratory model tests in a large-scale testing tank were performed to investigate the effect of geogrid encasement on the lateral and vertical deformations of stone columns installed in a clay bed. For comparison purposes, ordinary stone columns were also tested and evaluated. The main objective of this research is to investigate the lateral and vertical deformation patterns of the encased stone columns and the reinforcement mechanisms of the geogrid encasement with different encasement lengths. In addition, the stress-strain characteristics of the encasement were measured and analysed. The test results show that the ultimate load capacity of the soft soil was greatly increased by the geogrid-encased stone columns. The effective length of the encasement was three to four times of the diameter of stone columns based on the consideration of performance and economy. In comparison with the analytical solution based on the unit cell concept with full encasement of columns, the experimental tests on composite foundations with partially encased columns, which allowed lateral deformations of columns and soils and slippage along the column-soil interfaces (geogrid-soil, stone column-geogrid, and stone column-soil if the column is not encased), resulted in larger settlements, especially at higher vertical pressures.
\end{abstract}

KEYWORDS: Geosynthetics, Stone columns, Encasement, Deformation, Model tests

REFERENCE: Gu, M., Zhao, M., Zhang, L. and Han, J. (2016). Effects of geogrid encasement on lateral and vertical deformations of stone columns in model tests. Geosynthetics International, 23, No. 2, 100-112. [http://dx.doi.org/10.1680/jgein.15.00035]

\section{INTRODUCTION}

Stone columns have been extensively used to support structures on soft soils by increasing bearing capacities, reducing settlements, accelerating consolidation, and minimising liquefaction potential of soft or liquefiable ground (Barksdale and Bachus 1983; Priebe 1995; Han and Ye 2001). However, when the soft soils are extremely weak, the stone columns are not effective to provide their load capacity due to insufficient lateral confining stresses provided by the surrounding soils and even may not be adequate to form the columns during installation under an extreme condition. Geosynthetic encasement of individual stone columns is an effective method to improve the performance of the stone columns installed in such weak soils by providing additional confinement. As a result, the capacity and stiffness of the columns can be increased and the settlement of the soil strata can be 
further reduced. In the present study, the stone columns without any geosynthetic encasement is referred to as ordinary stone columns (OSC) whereas those with the geosynthetic encasement is referred to as the geosyntheticencased stone columns (GESC). The geosynthetic used for the encasement can be woven geotextile or geogrid. Geogrid was used in the present study. The geosynthetic encasement can be installed partially in the upper portion or fully along the whole column length (Murugesan and Rajagopal 2007; Yoo and Lee 2012).

Since the idea of encasing stone columns by wrapping with a geotextile was developed in 1980s (Van Impe 1989), the development of geosynthetic-encased stone columns has made much progress in the last two decades including the development of analytical methods, numerical analyses and experimental tests. Raithel and Kempfert (2000) developed an analytical model based on the axisymmetric unit cell concept to calculate the settlement of a soft foundation reinforced by geotextile-encased stone columns. Murugesan and Rajagopal (2006, 2010) evaluated the behaviour of ordinary and geosynthetic-encased stone columns by a finite-element analysis and investigated the improvement of the load capacity for stone columns by encasement through model tests in clay beds. The results indicated that the load capacity depended upon the modulus of the encasement and the diameter of the stone columns. Pulko et al. (2011) presented an analytical closed-form solution for the settlement of the encased stone column-reinforced foundation by taking into account elasto-plastic behaviour of the column material. Ghazavi and Afshar (2013) compared the effectiveness of encased stone columns with various diameters by laboratory tests. Gniel and Bouazza (2010) investigated the method for encasement construction in the model tests and indicated that the 'method of overlap' provided a level of connection similar to welding. Wu et al. (2009) evaluated the axial stress-strain relationships of encased granular columns using an analytical procedure based on the cavity expansion method. Their study found that reinforcement of a column with a sleeve within the top portion was adequate to prevent the column from bulging failure and also increased its load capacity. Gniel and Bouazza (2009) investigated the behaviour of geogridencased columns based on small-scale tests, in which the column diameter was $50.5 \mathrm{~mm}$. The bulging deformation of the partially encased stone columns was measured after the sample was extruded from the clay by using a rigid layer of plaster to cast the top of the sample and then bisected to observe the bulging deformation. During this process, the disturbance of the sample might happen and affect the actual lateral deformation.

Geosynthetic encasement can reduce lateral deformations of the column during installation and under loads and minimise inter-mixing of soft soil and aggregate in the column. Therefore, the encasement can minimise smearing of the surrounding soil and preserve the drainage property of the stone column. Murugesan and Rajagopal (2007) investigated and confirmed the benefit of geosynthetic encasement in reducing the lateral deformations of the column. The inter-mixing of soft soil and aggregate reduces the permeability and modulus of the column. As a result, the column will have more well resistance to drainage. Han and Ye (2002) demonstrated that smear and well resistance reduced the rate of consolidation of stone column-reinforced foundations. Castro and Sagaseta (2011) presented an analytical solution to study the settlement reduction and the acceleration of consolidation by encased stone columns. Their results showed the encasement had a negligible effect on the consolidation for an elastic column but had a positive effect when the column started to yield.

It is well understood that the most probable failure mechanism for OSC is lateral bulging failure (Black et al. 2007) if the columns are sufficiently long. With a full encasement, GESC may have less chance of having a bulging failure. However, partial encasement has complicated possible failure modes. Further research is needed to better understand the vertical and lateral deformations of GESC, especially for stone columns partially encased within the top portion. The degree of lateral deformation governs the bearing capacity and vertical deformation of the stone columns. In the present study, OSC and GESC were installed in clay beds subjected to vertical plate loading as shown in Figure 1. Two types of tests were conducted, one on an individual column and another on a composite foundation consisting of a column and its surrounding soil. The lateral deformations of the stone columns were measured using the strain gauges fixed on the geogrid ribs and the hoop displacement gauges wrapped around the unreinforced columns. These gauges monitored the deformations at every load increment. The effective encasement depth was also investigated by changing the length of the geogrid encasement along the stone columns. Earth pressure cells were installed to investigate the load transfer mechanisms between columns and soil and with depth. Details of the plate loading tests will be discussed later. Based on the results from the tests, an analytical solution based on a unit cell concept and full encasement was examined and the comparison indicated that lateral deformations and shear stresses along the column-soil interface resulted in large vertical deformations (settlements).

\section{DESCRIPTION OF EXPERIMENT}

\subsection{Properties of materials}

\subsubsection{Clay and stone column materials}

The clay soil was obtained from a lake bed of the Xiang River in the Changsha city, China. The moisture content of the in situ soil ranged from 30 to $60 \%$ and its undrained shear strength was below $15 \mathrm{kPa}$. This soil can be classified as $\mathrm{CH}$ based on the USCS. Two clay beds were prepared in the model tests using the clay soil at two different moisture contents, which corresponded to two different soil strengths to examine the effectiveness of geogrid encasement to improve stone columns in soft soils. The soil at the higher moisture content of 55.6\% represented a very soft soil whereas the soil at the lower moisture content of $40.5 \%$ represented a typical soft soil. 
Two plate loading tests with a circular plate diameter of $200 \mathrm{~mm}$ were conducted on the typical soft soil surface using a maintained load method. The average ultimate load capacity of these two plate loading tests was

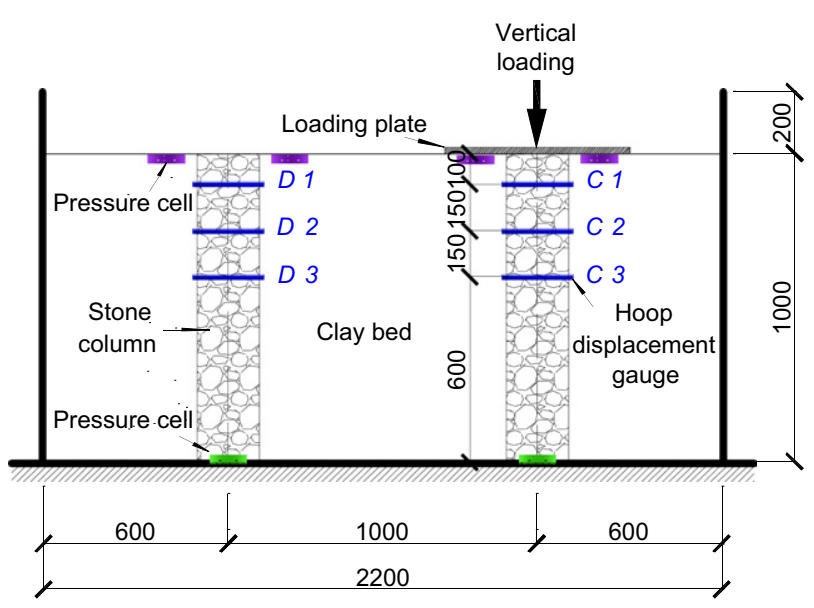

(a)

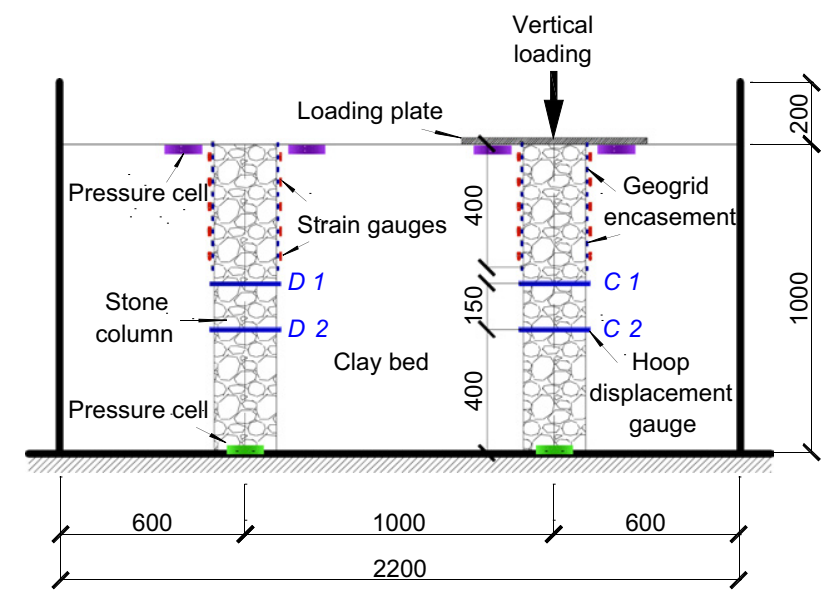

(b)

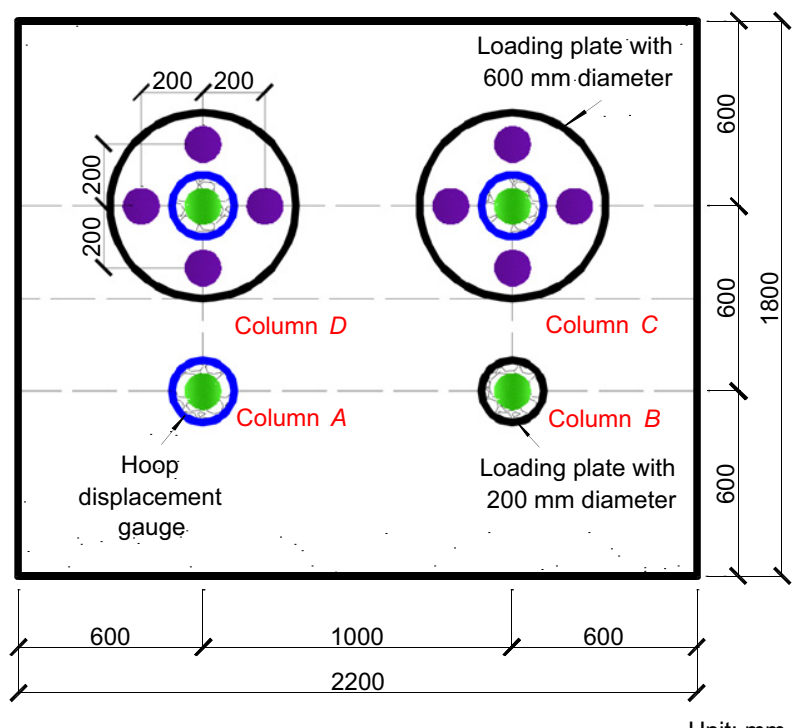

(c)

Unit: $\mathrm{mm}$

Figure 1. Load tests on stone columns. (a) ordinary stone columns (OSC); (b) geogrid-encased stone column (GESC2D) with the length of encasement sleeve $\mathbf{4 0 0} \mathrm{mm}$; (c) plan view of stone columns arrangement
$34.5 \mathrm{kPa}$. Using the Vesic method (Vesic, 1973), the undrained shear strength of the typical soft soil was backcalculated as $5.6 \mathrm{kPa}$ using the formula $q_{\mathrm{u}}=s_{\mathrm{c}} d_{\mathrm{c}} N_{\mathrm{c}} c_{\mathrm{u}}$, where $s_{\mathrm{c}}$ is the shape factor, 1.2 for this case; $d_{\mathrm{c}}$ is the depth factor, $1.0 ; N_{\mathrm{c}}=5.14$; and $c_{\mathrm{u}}$ is the undrained shear strength. As the very soft soil was too soft for the plate loading tests, an unconsolidated undrained (UU) triaxial test was conducted to estimate its undrained shear strength. The soil samples for triaxial tests were obtained from the clay bed using a sampling tube with a diameter of $50 \mathrm{~mm}$ and a height of $100 \mathrm{~mm}$. The soil samples were extruded from the tube and trimmed to the desired size (i.e. $38 \mathrm{~mm}$ in diameter and $76 \mathrm{~mm}$ in height) with great care to reduce the degree of disturbance. The detailed properties of the clay soils are listed in Table 1.

The aggregates used to form the columns were angular crushed stones and Figure 2 shows their particle size distribution. Other properties of the aggregates are provided in Table 2.

Table 1. Properties of clay soils

\begin{tabular}{|l|l|}
\hline Parameters & Value \\
\hline Liquid limit & 64.6 \\
Plastic limit & 35.2 \\
Plastic index & 29.4 \\
Specific gravity & 2.7 \\
Moisture content of clay 1 & $55.6 \%$ \\
Moisture content of clay 2 & $40.5 \%$ \\
Undrained shear strength of clay 1 & $3.4 \mathrm{kPa}$ \\
Undrained shear strength of clay 2 & $5.6 \mathrm{kPa}$ \\
USCS symbol & $\mathrm{CH}$ \\
\hline
\end{tabular}

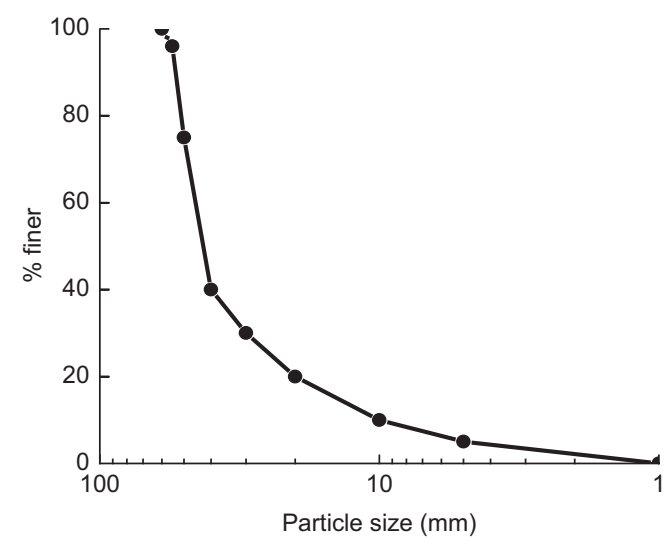

Figure 2. Particle size distribution for stone columns

Table 2. Properties of aggregates

\begin{tabular}{|l|l|}
\hline Parameters & Value \\
\hline Size range & $10-60 \mathrm{~mm}$ \\
$D_{10}, D_{30}$ and $D_{60}$ & 10,30 and $45 \mathrm{~mm}$ \\
Peak friction angle & $40.6^{\circ}$ \\
Specific gravity & 2.6 \\
Dry density & $1.65 \mathrm{~g} / \mathrm{cm}^{3}$ \\
Relative density & $72 \%$ \\
USCS symbol & GP \\
\hline
\end{tabular}




\subsubsection{Geogrid encasements}

A high-density polyethylene (HDPE) biaxial geogrid was adopted in the model tests and its strength and geometric properties are provided in Table 3. The encasement sleeve was formed by rolling a flat biaxial geogrid sheet into a cylinder with a diameter of $200 \mathrm{~mm}$. The sleeve in the circumferential direction had an 80-mm overlap and nylon cable ties were used to fix the encasement sleeve in the position to prevent it from unravelling during column construction and loading. This method was referred to as the 'method of overlap' by Gniel and Bouazza (2010), who investigated the method for encasement construction. The lengths of the encasement sleeve were varied in the model tests. Figure 3 presents a typical photograph of the geogrid encasement.

\subsection{Preparation of clay bed and stone columns}

The clay bed was prepared in a large test tank with a length of $2.2 \mathrm{~m}$, a width of $1.8 \mathrm{~m}$, and a depth of $1.2 \mathrm{~m}$. The inner wall surfaces of the test tank were covered with a $20 \mathrm{~mm}$-thick foam board and plastic sheets to reduce the boundary effects. The thickness of the clay bed was $1.0 \mathrm{~m}$ in all the model tests. The soft soils obtained from a lake bed were first divided into several portions of about $200 \mathrm{~kg}$ each. The natural moisture content of the soil in each portion was measured and additional water was added to achieve the desired moisture content of 55.6 or $40.5 \%$ for two different soil strengths. All the soils at the proper moisture content were subsequently mixed until they became uniform. The clay bed was prepared in layers with a lift thickness of $200 \mathrm{~mm}$. After the placement of each layer, a miniature cone penetrometer was used to evaluate the uniformity of the layer. The moisture contents of the soil were measured at eight different locations inside the test tank and the variation of the measured moisture contents was controlled within $1 \%$ difference.

Table 3. Properties of biaxial geogrid

\begin{tabular}{|l|l|}
\hline Parameters & Value \\
\hline Tensile strength at 2\% elongation & $13.6 \mathrm{kN} / \mathrm{m}$ \\
Tensile strength at 5\% elongation & $20.0 \mathrm{kN} / \mathrm{m}$ \\
Width of the rib & $5 \mathrm{~mm}$ \\
Mesh aperture size & $40 \mathrm{~mm} \times 40 \mathrm{~mm}$ \\
\hline
\end{tabular}
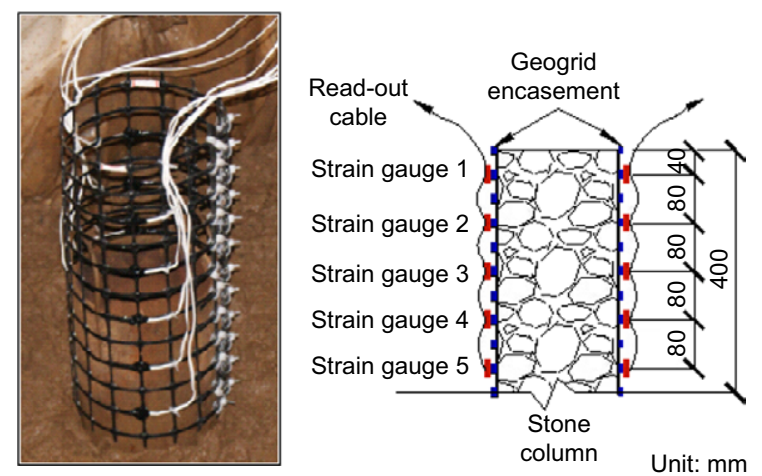

Figure 3. Strain gauges fixed on the geogrid encasement
A replacement method was adopted for the installation of stone columns. Four open-ended steel pipes with an outer diameter of $200 \mathrm{~mm}$ were placed at the proper locations in the test tank before the first soil layer was placed. Each steel pipe had a wall thickness of $3 \mathrm{~mm}$ and a length of $800 \mathrm{~mm}$. When the total thickness of the soil layers reached $400 \mathrm{~mm}$ (i.e. two lifts), aggregates of the calculated amount were filled into the pipes to form the stone column $400 \mathrm{~mm}$ high and well compacted by hand using a small steel pipe with a closed base $(50 \mathrm{~mm}$ in diameter and $15 \mathrm{~kg}$ mass) falling freely from a $300 \mathrm{~mm}$ height. The open-ended steel pipe was then pulled up gently by $200 \mathrm{~mm}$ in the vertical direction so that the pipe had a minimum embedment depth of $200 \mathrm{~mm}$ between the surrounding soil to maintain the stability of the pipe and the filled aggregates. The steel pipe was pulled up again after the next $200 \mathrm{~mm}$ thick soil was placed and the next stone column section was installed. The above procedure was repeated until the entire length of the stone column was formed. The total amount of aggregates used to form each stone column was recorded and adjusted to ensure the desired dry density of $1.65 \mathrm{~g} / \mathrm{cm}^{3}$ for the stone columns was achieved. For each encased stone column, the geogrid encasement was wrapped around the outer surface of the open-ended steel pipe at a specific depth to have a desired encasement length. When the steel pipe was pulled up, the location of the encasement was kept fixed by additional downward resistance applied by hand and the interlock forces between the aggregates and the geogrid.

The sizes of model tests were designed at a scale ratio of $1: 2.5$ to those of typical field tests. The diameter of the stone columns was $200 \mathrm{~mm}$, which corresponded to a field column size of $500 \mathrm{~mm}$. The geogrid used in the present study was a biaxial geogrid, which is also commonly used in the field. Biaxial geogrids have many varieties with a wide range of strengths, typically from 20 to $200 \mathrm{kN} / \mathrm{m}$. The geogrid used in the present study was one of the weakest ones. By considering the scale effect, the strength of the geogrid was still within the typical range. The aggregate size was selected based on the model scale effect and the geogrid aperture size $(40 \mathrm{~mm} \times 40 \mathrm{~mm})$. The mean grain size $\left(D_{50}\right)$ was $42 \mathrm{~mm}$, which was slightly larger than the geogrid aperture size. In practice, common sizes of aggregates used in the field are from 40 to $120 \mathrm{~mm}$. Hence, the ratio of the model aggregate size to the field size was within $1: 2.5$. As the depth of column bulging was observed to be three to four times the diameter of the stone column (e.g. Hughes and Withers 1974; Black et al. 2007), the column length to diameter ratio of 5 ensured the length of the column was greater than the typical depth of column bulging and was adopted in the model tests to investigate the bulging deformation of the stone columns. The dimensions of the test tank were chosen to accommodate four columns, which were used to simulate a single column and a composite foundation consisting of one column and its surrounding soil. The inner wall surfaces of the test tank were covered with a $20 \mathrm{~mm}$ thick foam board and plastic sheets to reduce the boundary effects. Tognon et al. (1999) showed that polyethylene plastic sheets placed on the walls of the tank could 
minimise the angle of friction between the walls and soil to less than $5^{\circ}$.

To monitor lateral deformations of an unreinforced stone column (including OSC and the unreinforced portions of GESC), a patented technology, so-called the hoop displacement gauge (Hunan University 2008) as shown in Figure 4, was installed around the column. The steel wire retracted in the gauge is gradually pulled out with the increased perimeter of the column due to lateral expansion under loading. The sensor measures the increased wire length, which is the circumferential displacement of the column. Figure 1 shows the required number and locations of the hoop displacement gauges used in different tests. When the GESCs were used, the hoop strains in the geogrid encasement at various locations were measured using strain gauges. The strain gauges were oriented along the circumferential direction of the encasement and fixed onto the geogrid just after a cylindrical geogrid sleeve was formed. The strain gauges were $3.5 \mathrm{~mm}$ wide width and had an electrical resistance of $120 \Omega$ with a gauge factor of 2.14. Figure 3 shows the locations of strain gauges on the geogrid encasement.

\subsection{Load tests on stone columns}

Plate loading tests were conducted on single columns and composite foundations consisting of one column and its surrounding soil in the present study as shown in Figure 1. Figure 5 shows the plate load test set-up. The vertical load was applied in eight to ten increments to the loading plate using an air cylinder against a reaction frame for each load test. When each load increment was applied, the load was maintained constant until the rate of the settlement was less than $0.1 \mathrm{~mm} / \mathrm{h}$ and then the next load was applied. The load tests were terminated when the vertical load could not be maintained and the soil failed. The maintained load test method used in the present study was different from the maintained displacement rate method used by other researchers (Murugesan and Rajagopal 2010; Ghazavi and Afshar 2013). The maintained load test method could better simulate the process of embankment construction in the field.

Four series of plate loading tests were conducted by varying the length of the encasement sleeve and the undrained shear strength of the soil. Four stone columns (labelled A, B, C, and D) were installed in the clay bed for each series of test as shown in Figure 1. Columns A and B were loaded to simulate single stone columns with a

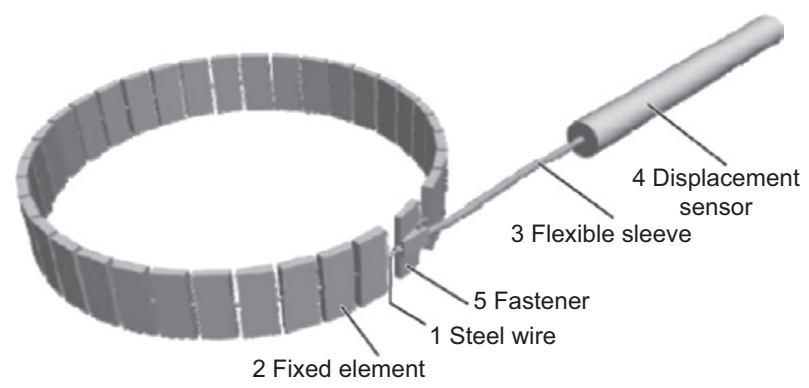

Figure 4. Hoop displacement gauge

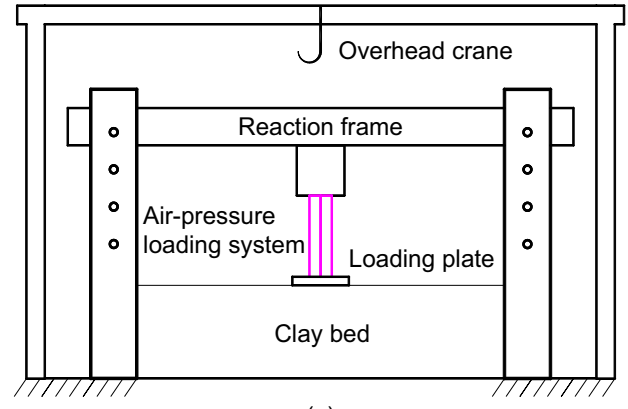

(a)

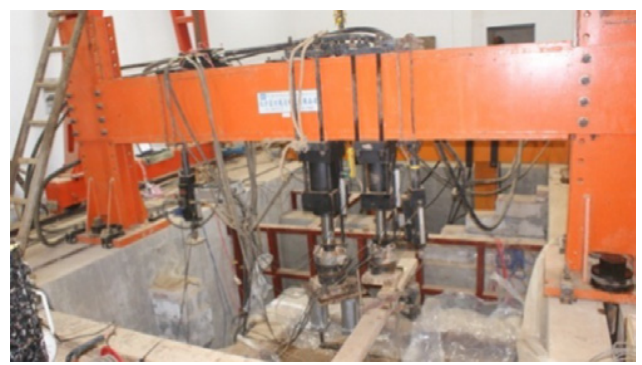

(b)

Figure 5. Testing set-up: (a) schematic of the loading system; (b) photograph of the plate load test

loading plate of $200 \mathrm{~mm}$ diameter. Columns $\mathrm{C}$ and $\mathrm{D}$ were included in the composite foundations loaded with a loading plate of $600 \mathrm{~mm}$ diameter, which was three times that of the stone column. The area replacement ratio of the columns under the loading plate in the composite foundation test was 0.11 .

The first series of tests was performed on OSC, which did not have any geosynthetic encasement. The second series of tests was performed on GESC with an encasement length of $400 \mathrm{~mm}$. The third and fourth series of tests were performed on GESC with encasement lengths of 600 and $800 \mathrm{~mm}$, respectively. Table 4 summarises the programme of the plate load tests conducted on the stone columns.

\section{RESULTS AND DISCUSSION}

\subsection{Load-settlement behaviour}

Figure 6 shows the applied pressure-settlement curves for OSC and GESC installed in the clay bed with an undrained shear strength of $3.4 \mathrm{kPa}$. The letters 'A, B, $\mathrm{C}$, and D' after ' $/$ ' refer to columns $\mathrm{A}, \mathrm{B}, \mathrm{C}$, and $\mathrm{D}$, respectively. These results were obtained from the plate loading tests on both the single stone columns and the composite foundations consisting of columns with the surrounding soil. They can be used to compare their relative performance and verify the effectiveness of the geogrid encasement for the improvement of stone columns in very soft soils. Figure 6(a) shows that the ultimate bearing capacity of the single OSC was $80 \mathrm{kPa}$, which corresponded to the plate settlement of $40 \mathrm{~mm}$ (i.e. $20 \%$ the plate diameter). Therefore, the ratio of the ultimate bearing capacity of the single OSC to the undrained shear strength of the soil was 23.6 , which is close to 20 as 
Table 4. Plate loading tests on single stone columns and composite foundations

\begin{tabular}{|c|c|c|c|c|}
\hline Test type & $\begin{array}{l}\text { Test } \\
\text { description }\end{array}$ & $\begin{array}{l}\text { Length of geogrid } \\
\text { encasement }(\mathrm{mm})\end{array}$ & $\begin{array}{l}\text { Soil undrained } \\
\text { strength }(\mathrm{kPa})\end{array}$ & $\begin{array}{c}\text { Total number } \\
\text { of tests }\end{array}$ \\
\hline $\begin{array}{l}\text { Single stone column } \\
\text { Composite foundation with a column }\end{array}$ & $\begin{array}{l}\text { OSC } \\
\text { GESC2D } \\
\text { GESC3D } \\
\text { GESC4D } \\
\text { OSC } \\
\text { GESC2D } \\
\text { GESC3D } \\
\text { GESC4D }\end{array}$ & $\begin{array}{r}0 \\
400 \\
600 \\
800 \\
0 \\
400 \\
600 \\
800\end{array}$ & $\begin{array}{l}3.4 \\
3.4 \\
5.6 \\
5.6 \\
3.4 \\
3.4 \\
5.6 \\
5.6\end{array}$ & $\begin{array}{l}2 \\
2 \\
2 \\
2 \\
2 \\
2 \\
2 \\
2\end{array}$ \\
\hline
\end{tabular}

OSC, ordinary stone column; GESC2D, geogrid-encased stone column with the encasement length of twice its diameter (D), and GESC3D and GESC4D, geogrid-encased stone columns with the encasement lengths of three and four times its diameter $(D)$, respectively.

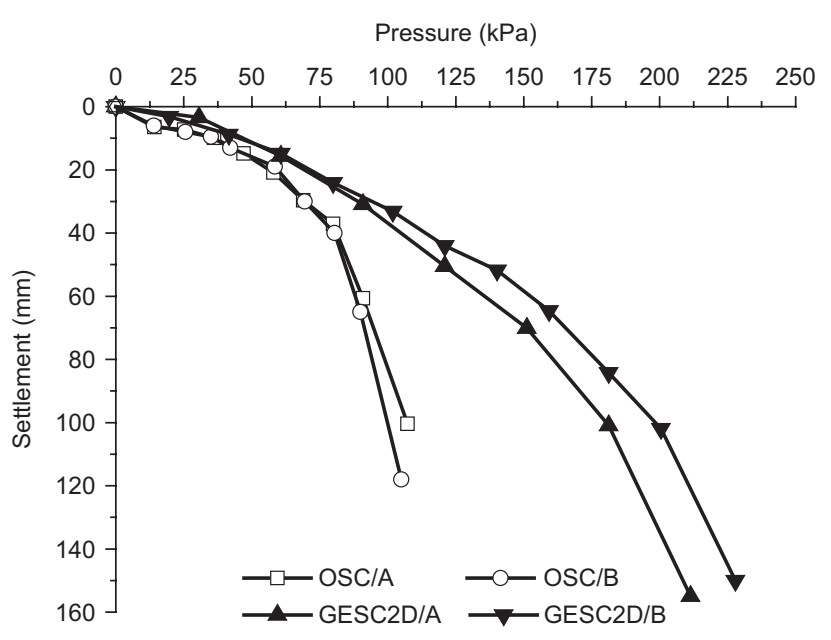

(a)

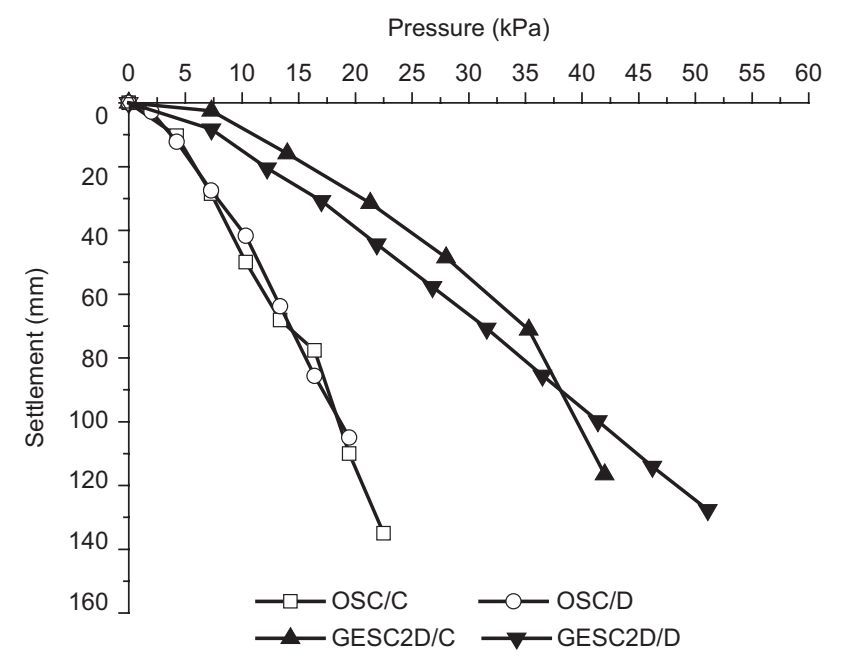

(b)

Figure 6. Applied pressure-settlement responses of the stone columns installed in the clay bed with an undrained shear strength of $3.4 \mathrm{kPa}$ : (a) single stone columns and (b) composite foundations

suggested by Han (2015). However, the pressure on the single GESC at the settlement of $40 \mathrm{~mm}$ (i.e. $20 \%$ the plate diameter) was about $120 \mathrm{kPa}$, which is 1.5 times that on the single OSC $(80 \mathrm{kPa})$. As discussed later, the OSC bulged quickly with the increase of the applied pressure from 35 to $90 \mathrm{kPa}$ whereas the single GESC deformed less. The GESC could carry an even higher pressure up to a large settlement $(100 \mathrm{~mm})$. Figure 6(b) shows the test results from the composite foundation load tests. The ultimate bearing capacity of the composite foundation with the OSC at the settlement of $120 \mathrm{~mm}$ (i.e. $20 \%$ the plate diameter) was $21 \mathrm{kPa}$ whereas the ultimate bearing capacity of the composite foundation with the GESC2D was $45 \mathrm{kPa}$. Therefore, the geogrid encasement increased the ultimate bearing capacity of the composite foundation the GESC2D by 2.1 times in comparison with that for the OSC.

Figure 7 illustrates a comparison of the normalised pressure-settlement responses of the stone columns with various encasement lengths. To evaluate the relative performance of the stone columns installed in the clay beds with two different shear strengths, two dimensionless parameters, pressure/ $c_{\mathrm{u}}$ and settlement/ $d$, were adopted in this analysis, where $c_{\mathrm{u}}$ is the undrained shear strength of the soil and $d$ is diameter of the loading plate. In the tests with the plate on OSC and GESC2D, the undrained shear strength of the soil, $c_{\mathrm{u}}$, was $3.4 \mathrm{kPa}$ and the diameter of the loading plate, $d$, was $200 \mathrm{~mm}$ for single stone columns and $600 \mathrm{~mm}$ for the composite foundations. In the tests on GESC3D and GESC4D, the value of $c_{\mathrm{u}}$ was $5.6 \mathrm{kPa}$ and the value of $d$ was $200 \mathrm{~mm}$ for single stone columns or $600 \mathrm{~mm}$ for the composite foundations.

Figure 7 shows that the bearing capacities of single GESCs and the composite foundations with GESCs were much higher than single OSCs and those with OSCs, respectively when the encasement length was three or four times the diameter of the column. Figure 7(a) shows that the stiffness of the stone column increased with the increase of the encasement length. However, the pressuresettlement responses were almost the same for both single GESC3D and the GESC4D and the composite foundations with GESC3D and the GESC4D. In other words, a further increase of the encasement length did not provide any additional contribution to the stiffness and bearing capacity of the column. This result was attributed to similar lateral deformations and confining stresses developed at the interface between the encasement and the stone column, which will be further discussed in the following sections.

Table 5 illustrates the error between the measured bearing capacity for the composite foundations and the calculated value from single columns using the formula 
$q_{\mathrm{u}, \mathrm{c}}=q_{\mathrm{c}} A_{\mathrm{r}}+q_{\mathrm{s}}\left(1-A_{\mathrm{r}}\right)$, where $q_{\mathrm{c}}$ and $q_{\mathrm{s}}$ are the bearing capacity of the single column and the soil, respectively, and $A_{\mathrm{r}}$ is the area replacement ratio. The error is defined as: $e=\left(q_{\mathrm{u}, \mathrm{c}}-q_{\mathrm{u}, \mathrm{m}}\right) / q_{\mathrm{u}, \mathrm{m}}$, where $q_{\mathrm{u}, \mathrm{c}}$ and $q_{\mathrm{u}, \mathrm{m}}$ are the calculated and measured bearing capacities for the composite foundation, respectively. The calculated bearing capacity for OSC was $22.1 \%$ greater than the measured one and the maximum error for GESC was $17.6 \%$ smaller compared with the measured bearing capacity, which was

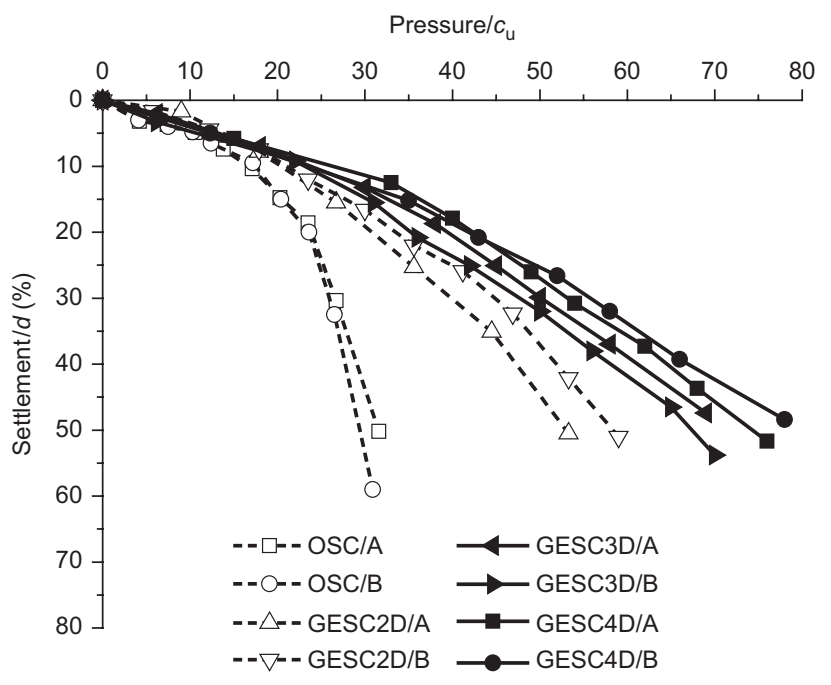

(a)

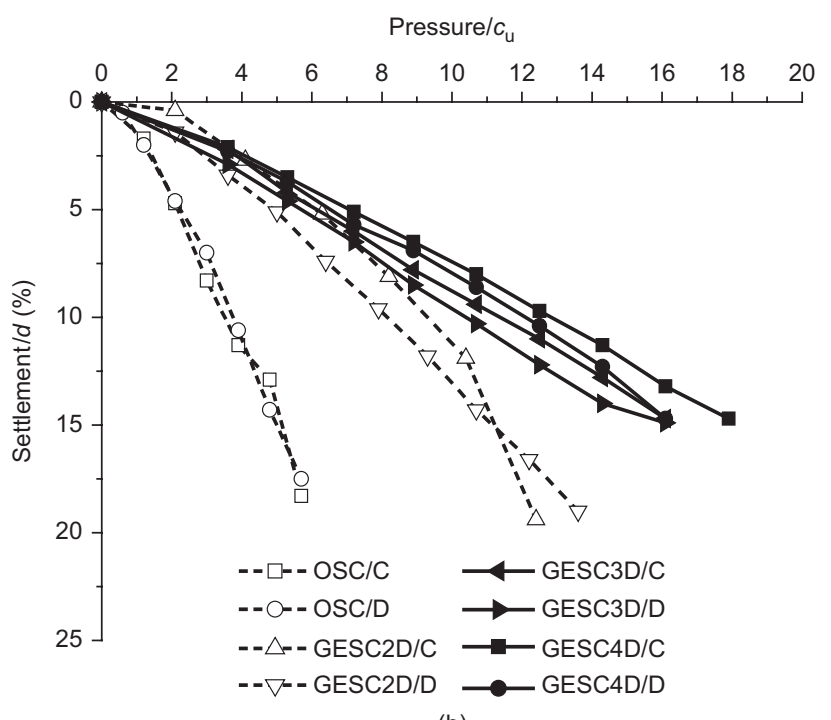

(b)

Figure 7. Normalised pressure-settlement responses of stone columns with various encasement lengths: (a) single stone columns within a reasonable error range and demonstrated that the measured results were reliable.

\subsection{Lateral deformation}

The processes of lateral deformation of stone columns, often referred to as bulging, developing at every loading increment are depicted in Figures 8 and 9. Figure 8 presents the test results of the single stone columns and Figure 9 presents those of the composite foundations. The circumferential strains $\left(\varepsilon_{\varphi}\right)$ developing along the depths of the stone columns encased with the geogrid sleeve were measured using the strain gauges fixed at $80 \mathrm{~mm}$ intervals vertically. Considering the axial symmetry for the cylindrical stone columns, the values of circumferential strains were equal to those of radial strains $\left(\varepsilon_{\varphi}=\varepsilon_{\mathrm{r}}\right)$. The circumferential displacement $\left(\delta_{\varphi}\right)$ of OSC and the unreinforced portion of GESC were measured using the hoop displacement gauges, and thus the radial strain could be calculated as $\varepsilon_{\mathrm{r}}=\varepsilon_{\varphi}=\delta_{\varphi} /(\pi D)$, where $D$ is the diameter of the stone columns.

Figure 8 shows the radial strain profiles of the single stone columns installed in the clay bed and subjected to the vertical pressures. Figure 8(a) shows that the radial strain of the OSC decreased with the depth but increased with the applied pressure. The radial strain patterns of the GESCs in Figures 8(b) to 8(d) were different from that of the OSC due to the influence of the geogrid encasements with different lengths. Figure 8(b) shows that the upper portion of the GESC with the geogrid encasement had small radial strains because of the geogrid confinement but the lower portion without the geogrid encasement had larger radial strains. It is clearly shown that the geogrid encasement significantly reduced the lateral deformation in the upper portion of the column. For example, the maximum radial strain of the single OSC was $14 \%$ observed at the depth of $400 \mathrm{~mm}$, whereas it was only $4.5 \%$ of the single GESC2D and GESC3D within the unreinforced portion. The maximum radial strain of the single GESC4D was about $2.1 \%$ within the encased portion. In addition, the maximum radial strain portion of the stone column moved downward with the increase of the encasement length. Both Figure 8(a) and 9(a) show that the lateral deformations of the OSC mainly occurred within the upper portion (i.e. about two times the diameter of the column). However, the maximum radial strains in the GESC2D and GESC3D as shown in Figures 8(b), 8(c), 9(b) and 9(c) happened in the lower portions of the columns, which were below the encasement sleeves. Figures 8(d) and 9(d) show that the radial strains in the GESC4D were different from

Table 5. Comparison between measured and calculated bearing capacities for composite foundation

\begin{tabular}{|l|l|l|r|r|r|r|}
\hline Type & Measured or calculated & Symbol & OSC & GESC2D & GESC3D & GESC4D \\
\hline Soil & Measured $(\mathrm{kPa})$ & $q_{\mathrm{s}}$ & 21.0 & 21.0 & 34.5 & 34.5 \\
Column & Measured $(\mathrm{kPa})$ & $q_{\mathrm{c}}$ & 80.1 & 125.6 & 196.2 & 224.0 \\
Composite foundation & Measured $(\mathrm{kPa})$ & $q_{\mathrm{u}, \mathrm{m}}$ & 22.5 & 35.3 & 59.9 & 67.2 \\
& Calculated $(\mathrm{kPa})$ & $q_{\mathrm{u}, \mathrm{c}}$ & 27.5 & 32.4 & 52.3 & 55.3 \\
& Error $(\%)$ & $e$ & 22.1 & 8.0 & 12.7 & 17.6 \\
\hline
\end{tabular}




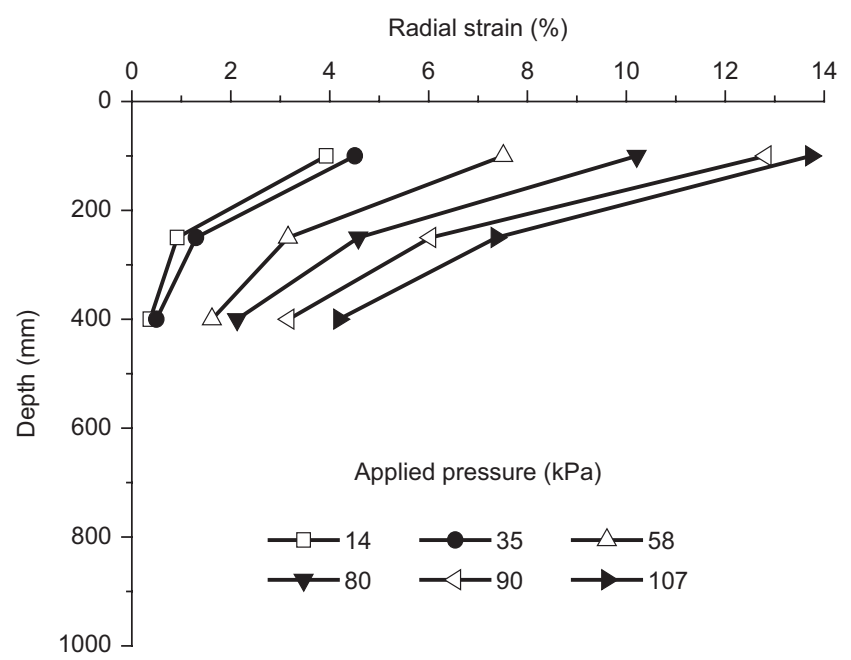

(a)

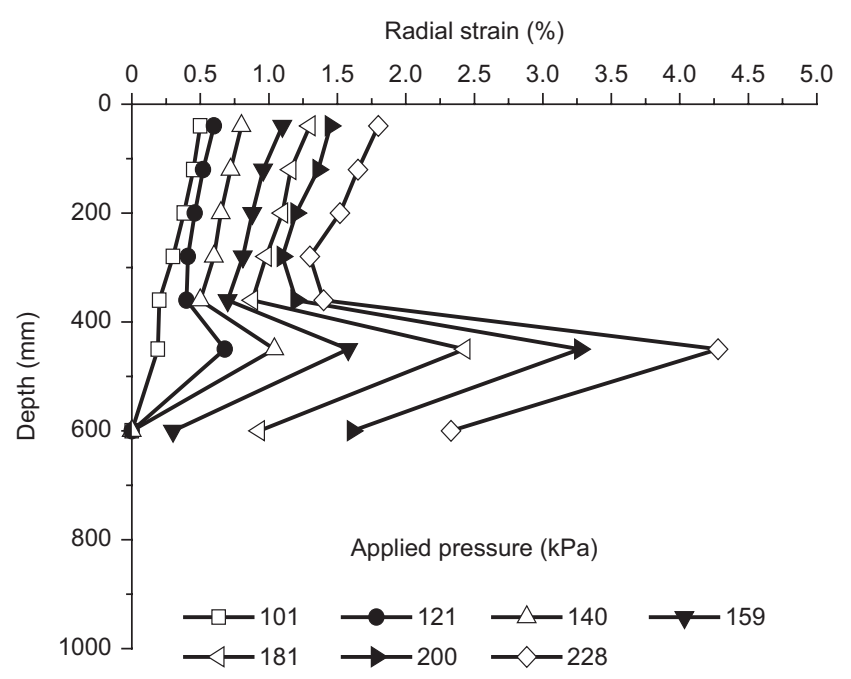

(b)

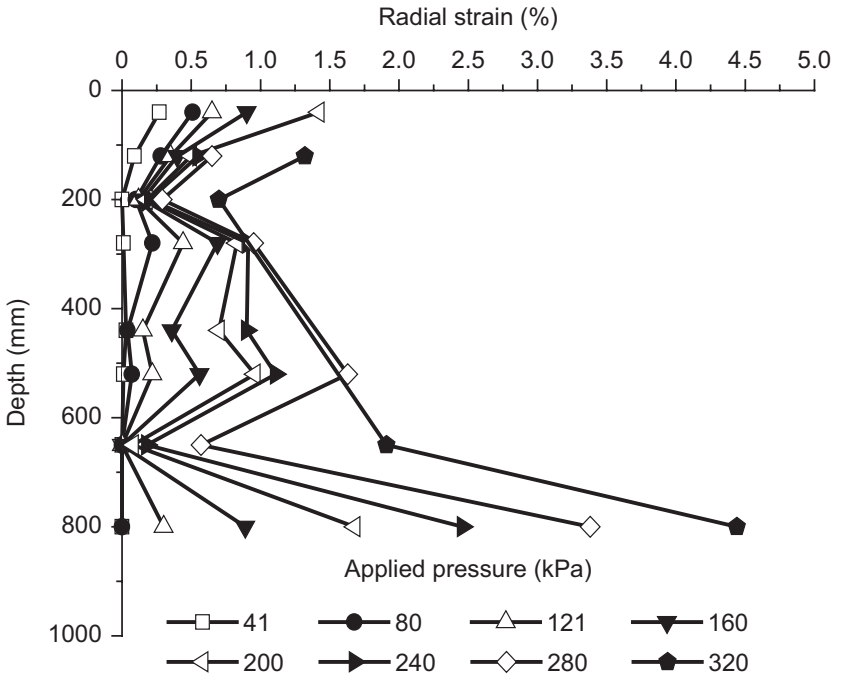

(c)

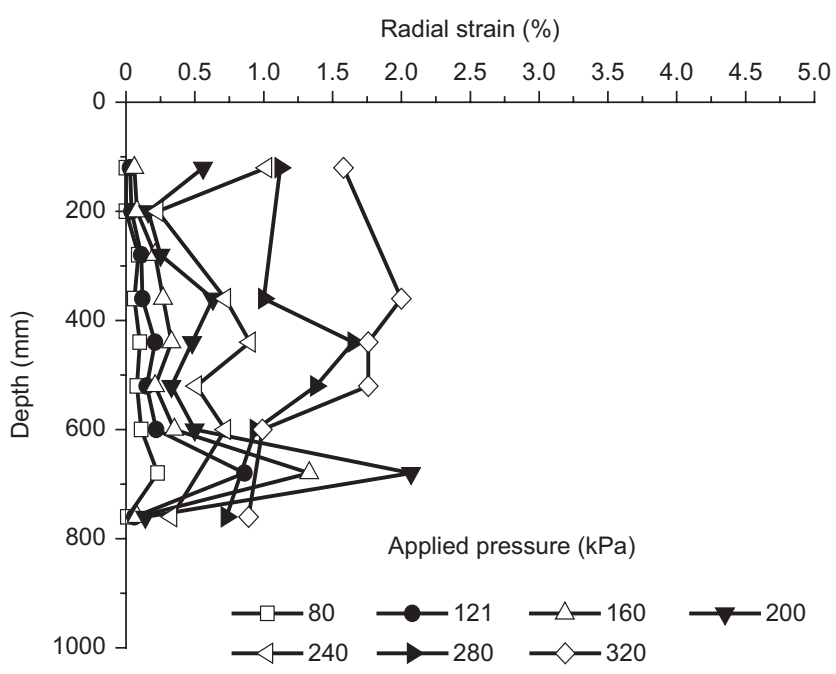

(d)

Figure 8. Radial strains in the single stone columns with various encasement lengths: (a) OSC, (b) GESC2D, (c) GESC3D, and (d) GESC4D

those in the GESC2D and GESC3D. The maximum radial strains occurred at a depth of twice the diameter of the column within the encased portion.

The measured radial strains as discussed above clearly show the pattern of the lateral deformation of the stone column depended on the length of geogrid encasement. The OSC failed due to insufficient lateral confining pressure offered by the surrounding soil at the shallow depth. For the geogrid-encased stone columns, the encasement sleeve could generate hoop stresses to confine the lateral deformation of the stone columns. At the beginning of loading, the upper encased portion of the column had a larger radial strain than the lower portion because higher stresses occurred within the upper portion and the geogrid encasement did not mobilise its resistance. With an increase of loading, the lateral deformation within the upper portion mobilised its resistance. As a result, the lateral deformation within the upper portion was restrained and the load was transferred to the lower portion so that the lateral deformations within the lower unreinforced section increased and exceeded the maximum deformation within the upper encased portion. In addition, the GESC failed due to the large bulging deformation of the unreinforced portion below the encasement sleeve.

Based on the four series of model test results, it can be concluded that the location of the bulging failure of stone columns changed with the length of geogrid encasement (from zero to four times the diameter of the stone columns) and the bulging deformation and failure governed the vertical settlement and bearing capacity of the GESC.

\subsection{Stress concentration ratio}

The pressures on the surrounding soil at the ground surface were measured using the earth pressure cells installed under the loading plate. The pressure transferred to the bottom of the stone column was measured using the earth pressure cell installed at the bottom of the model tank. Figure 1 shows the locations of the pressure cells. The stress concentration ratio of the stone column was calculated as the ratio of the pressure on the stone 


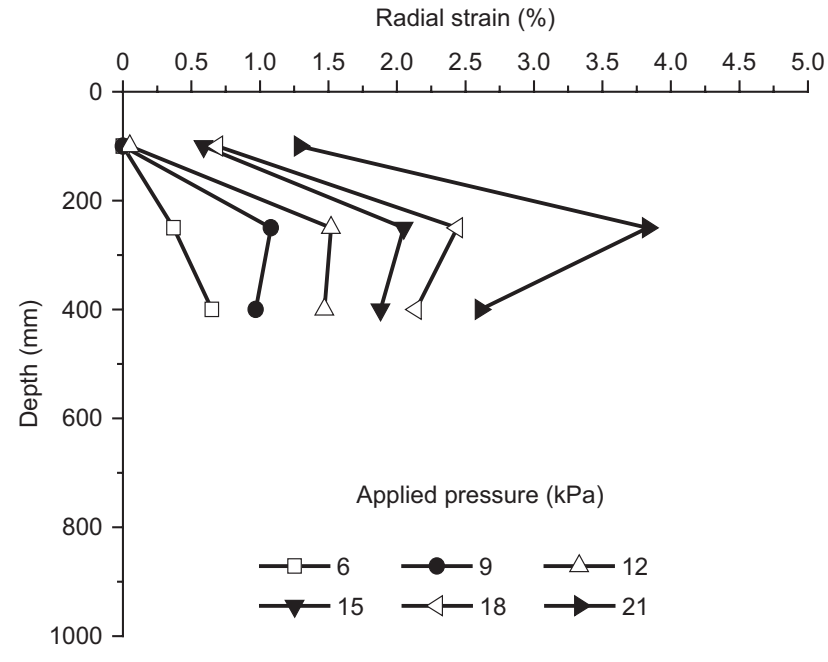

(a)

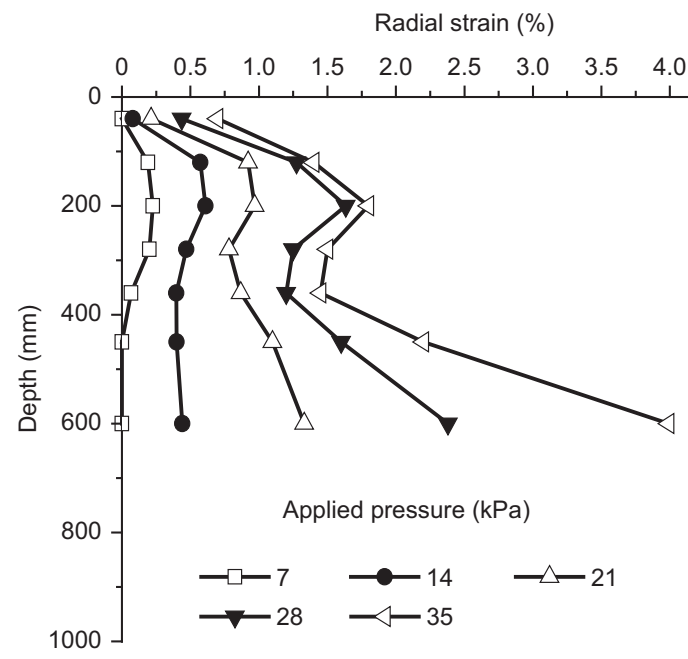

(b)

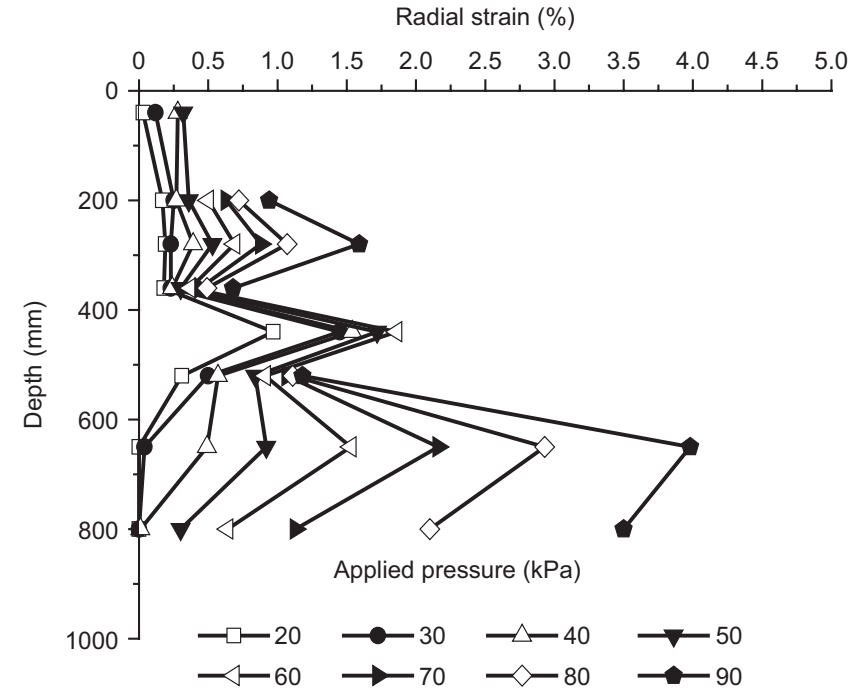

(c)

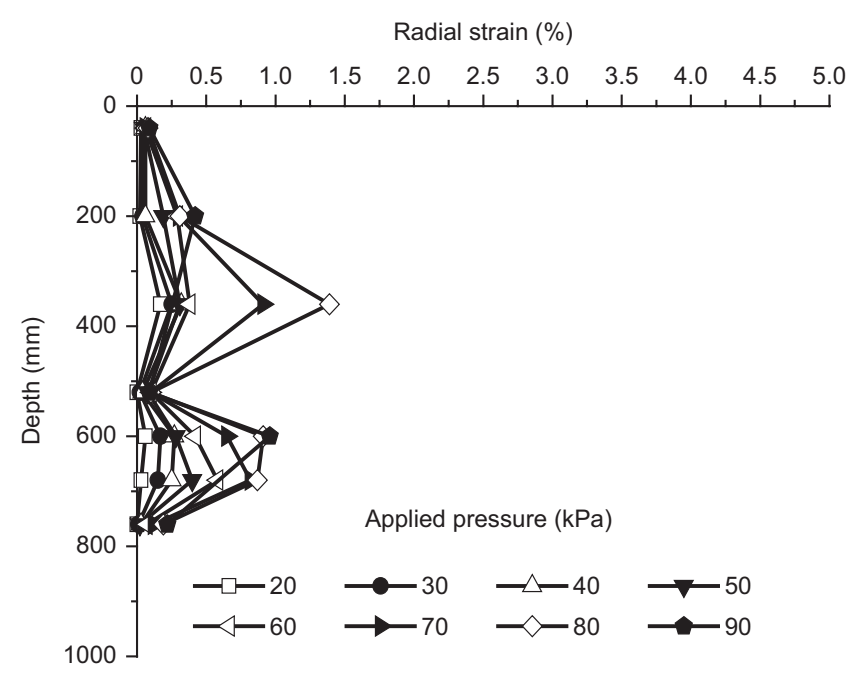

(d)

Figure 9. Radial strains of stone columns in composite foundations with various encasement lengths: (a) OSC, (b) GESC2D, (c) GESC3D, and (d) GESC4D

column to the pressure on the surrounding soil. Based on the vertical force equilibrium, at the ground surface, the pressure on the column $\left(\sigma_{\mathrm{cl}}\right)$ was calculated as: $\sigma_{\mathrm{cl}}=$ $\left[q_{\mathrm{A}} r_{\mathrm{e}}^{2}-\sigma_{\mathrm{s} 1}\left(r_{\mathrm{e}}^{2}-\mathrm{r}_{\mathrm{c}}^{2}\right)\right] /\left(r_{\mathrm{c}}^{2}\right)$, where $q_{\mathrm{A}}$ is the applied vertical load, $\sigma_{\mathrm{s} 1}$ is the mean value of earth pressure cells installed under the loading plate, and $r_{\mathrm{c}}$ and $r_{\mathrm{e}}$ are the radius of the stone column and loading plate, respectively. To evaluate the stress transfer from the top of the column to the bottom of the column, a ratio of the stress at the bottom to that at the top, referred to as the stress reduction ratio, can be calculated. Figure 10 shows the calculated stress concentration ratio plotted against the normalised settlement for the OSC and GESC at the ground surface and the stress reduction ratio from the top to the bottom of the column. The pressure cells in the fourth series test malfunctioned; therefore, no data was recorded. Figure 10(a) shows that the GESC resulted in the higher stress concentration ratio at the ground surface than the OSC. This result indicates that the GESC had higher stiffness than the OSC. The GESC carried more load than the
OSC at the same settlement. In addition, Figure 10(b) shows that the stress reduction ratio of the GESC was higher than that of the OSC at the earlier stage of loading, which means more load transferred from the top of the column to the bottom of the column. Figure 10(c) shows the failure mechanisms of the OSC observed in the model tests. The stress reduction ratio of the OSC decreased due to the mobilisation of bulging failure (which happened in the portion shown by the dash lines of $\left.a b c-c^{\prime} b^{\prime} a^{\prime}\right)$ and increased again because a new shear zone developed in the bulging area (which developed in the portion shown by the dash lines of ac- $\mathrm{c}^{\prime} \mathrm{a}^{\prime}$ ), thus the column acted like a pile and more load was transferred to the bottom. Figure 10(d) shows the failure mechanisms of the GESC observed in the model tests. The stress reduction ratio of the GESC increased firstly due to the slippage between the interfaces of the encasement and the soil, which happened in the encased portion of $a b-b^{\prime} a^{\prime}$, and then decreased because the bulging happened within the unreinforced section at the lower portion of the column (the portion shown by 


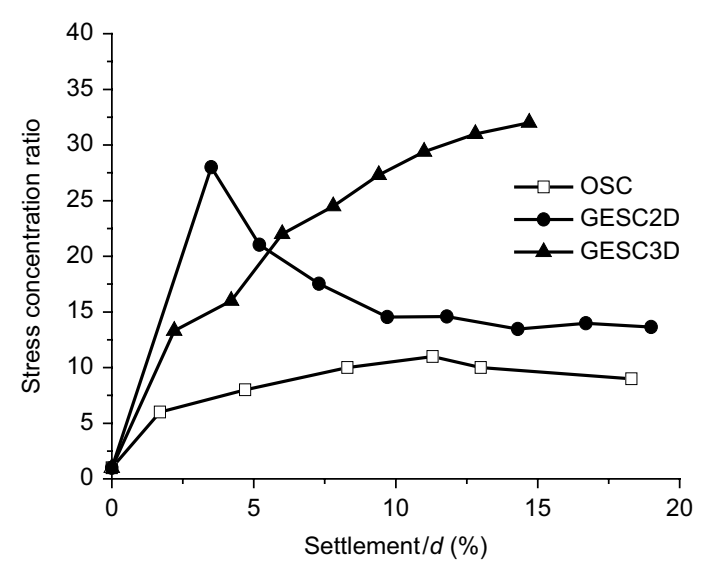

(a)

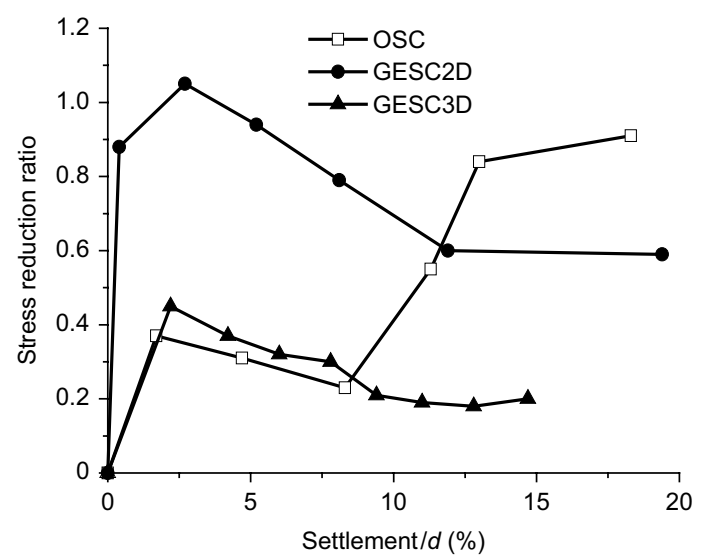

(b)

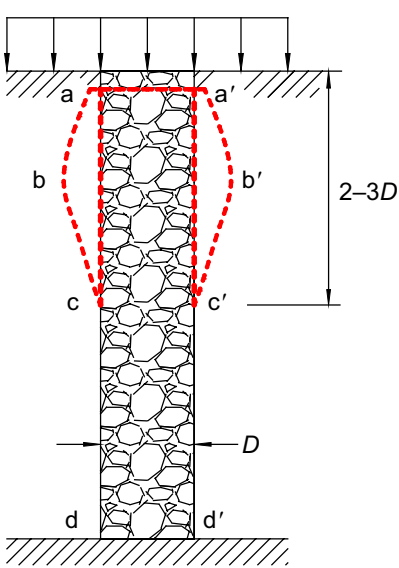

(c)

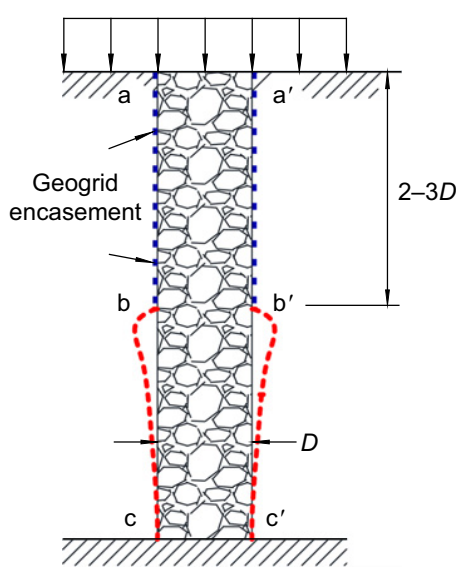

(d)

Figure 10. (a) Stress concentration ratio plotted against settlement at the ground surface, (b) stress reduction ratio, (c) failure mechanisms of the OSC (modified from Barksdale and Bachus 1983), (d) failure mechanisms of the GESC ( $d$ was the diameter of the loading plate, $D$ was the diameter of the column)

the dash lines of $\left.b c-c^{\prime} b^{\prime}\right)$. The stress reduction ratio of the GESC3D was even lower than that of the GESC2D because the surrounding soil around the GESC3D had a higher soil strength (also stiffness) than the soil around the GESC2D. The soil with higher strength carried more load and provided more friction resistance to the column.

\subsection{Hoop stress of the encasement}

The hoop strains in the grogrid encasements at different heights of the stone column were measured using strain gauges fixed at $80 \mathrm{~mm}$ vertical intervals. Two strain gauges were installed on the opposite sides of the column at the same elevation as shown in Figure 4. The actual hoop strain at each elevation was calculated as the average value of the two measured strains. Figures 8 and 9 show the hoop strains in the GESC with different encasement lengths. It can be observed that the maximum hoop strain was smaller than $2 \%$ in all model tests. The hoop force generated by the encasement sleeve can be calculated as: $F=E_{\mathrm{s}} \varepsilon_{\varphi}$, where $\varepsilon_{\varphi}$ and $E_{\mathrm{s}}$ are the hoop strain and the $2 \%$ secant modulus of the geogrid encasement, respectively. The radial confining stress provided by the encasement becomes (Pulko et al. 2011): $\sigma_{\mathrm{r}}=F /\left(2 r_{\mathrm{c}}\right)=E_{\mathrm{s}} \varepsilon_{\varphi} /\left(2 r_{\mathrm{c}}\right)$, where $r_{\mathrm{c}}$ is the radius of the stone column. Figure 11 shows the radial stress plotted against the settlement of the GESC with different encasement lengths. It is shown that the radial stresses provided by the encasement sleeve were not constant during loading for all stone columns and varied with the settlement. The radial stresses varied from 70 to $80 \mathrm{kPa}, 20$ to $60 \mathrm{kPa}$ and 10 to $50 \mathrm{kPa}$ for the columns with encasement lengths of 400, 600 and $800 \mathrm{~mm}$, respectively at the settlement of $50 \mathrm{~mm}$. The GESC3D and GESC4D had lower radial stresses from the geogrid encasement than the GESC2D and higher load capacities because of their higher stiffness resulting from the longer encasement sleeves. Therefore, the stone column with a long encasement sleeve was more robust and stiffer than that with a short encasement sleeve.

\subsection{Influence of encasement length}

Figure 7 shows the effect of the encasement length of the normalised pressure-settlement responses of the stone columns. It can be observed that the stiffness of the stone columns increased with the increase in the encasement length from $0,400,600$ to $800 \mathrm{~mm}$. The improved performance due to the geogrid encasement can be attributed to the additional confining stresses provided by the geogrid encasement. The effective length of the encasement can be examined from the comparative performance on the load capacities as shown in Figure 12. The load capacity of the stone columns at $50 \mathrm{~mm}$ settlement increased greatly when the encasement length changed from 0 to 


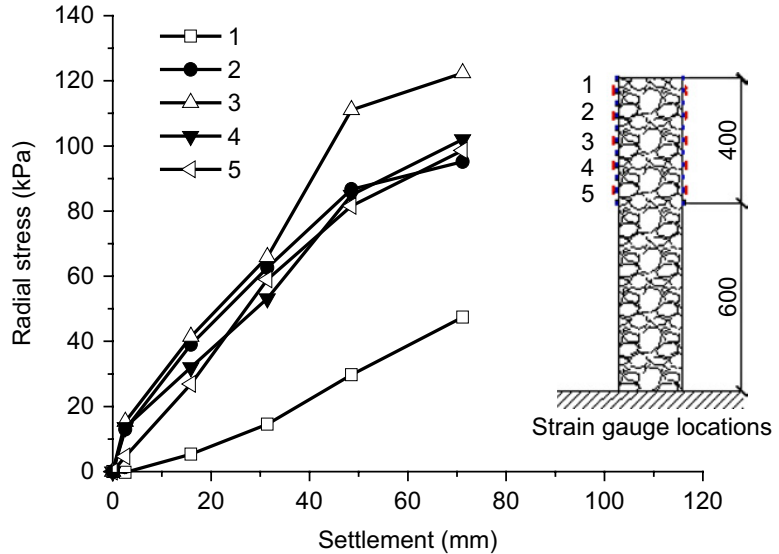

(a)

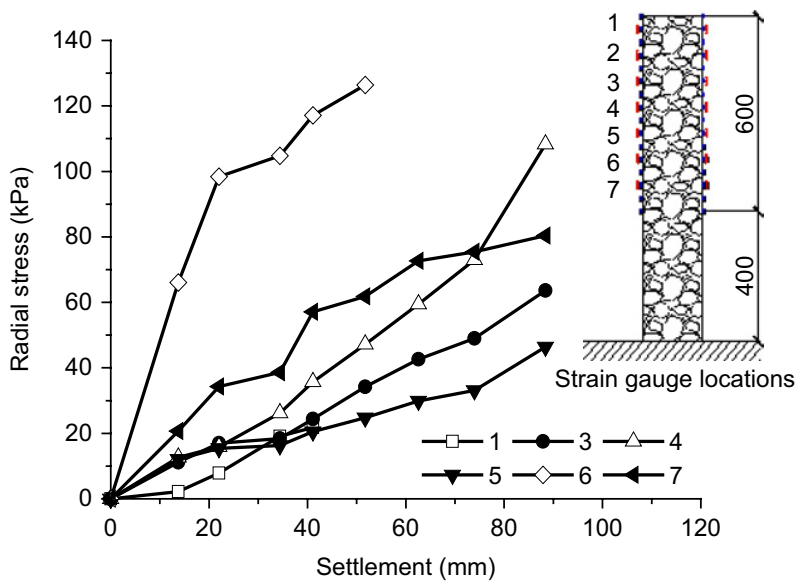

(b)

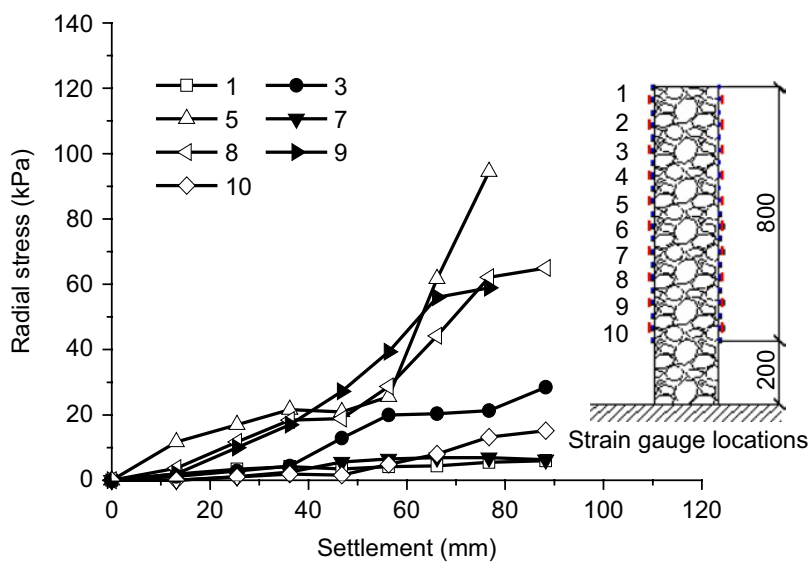

(c)

Figure 11. Radial stresses provided by the geogrid encasement around the stone column in the composite foundation: (a) GESC2D, (b) GESC3D, (c) GESC4D

$600 \mathrm{~mm}$ (three times the diameter). However, the load capacity of the GESC4D was almost the same as that of the GESC3D. This result implies that the effective length of the encasement was three times the diameter of the column and a further increase of the encasement length did not contribute to additional load capacity because the bulging failure occurred within the upper portion of the column and the confining stress provided by the encasement was fully mobilised. This effective

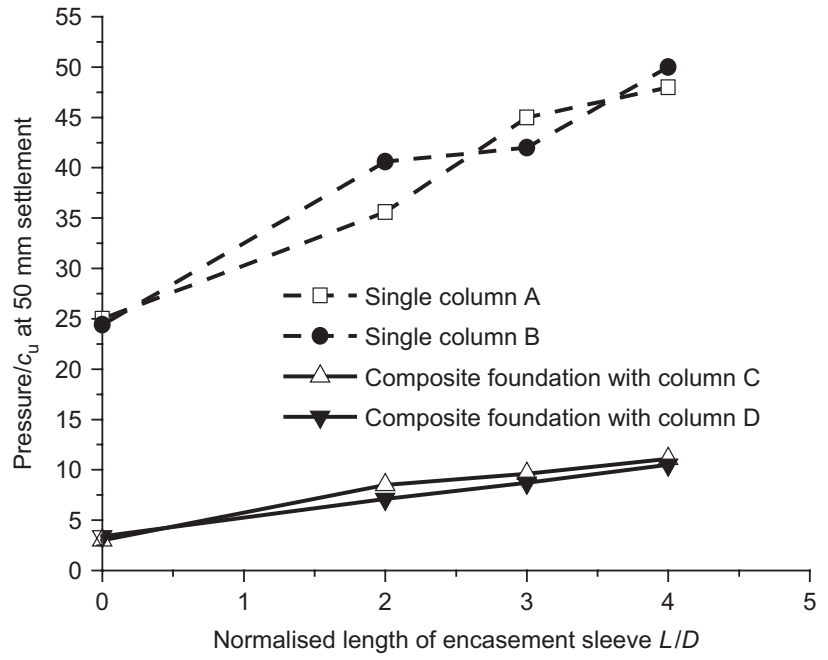

Figure 12. Influence of encasement lengths on the performance of stone columns ( $D$ is the diameter of the stone column)

encasement length should depend on the properties of the stone column, the encasement and the surrounding soils.

\section{COMPARISON WITH ANALYTICAL SOLUTION}

The available methods for the design of GESC include simplified analytical solutions and numerical methods. The analytical solutions were mostly developed based on the unit cell concept, which consisted of one stone column and its surrounding soil in a zone of influence. The analytical solution proposed by Pulko et al. (2011) for the design of GESC considers important factors, is well accepted and therefore was adopted in the present study for comparison with the experimental results. This solution takes into account the elasto-plastic behaviour of the stone column, which is important for simulating the actual performance of geosynthetic-encased stone columns under vertical loads. Pulko et al. (2011) assumed that the surrounding soil and the geosynthetic are elastic, the column has a full encasement length, and the column and the soil deform one-dimensionally at the same rate (i.e. no slippage and friction at the interface) under a drained condition. Even though the test condition is not exactly the same as a unit cell, the analytical solution can be considered as an ideal condition and is used as a reference to evaluate the experimental data.

The complete elasto-plastic response of a unit cell is described by a combination of elastic and elasto-plastic formulae. First, the yield depth in the stone column under a given load is determined as: $z^{\mathrm{y}}=q_{\mathrm{A}} /\left(C_{4} \gamma_{\mathrm{s}}\right)$, where $q_{\mathrm{A}}$ is the applied vertical load, $C_{4}$ is a constant and dependent on the properties of the column and the soil, $\gamma_{\mathrm{s}}$ is the soil unit weight. The vertical deformation of the unit cell can be calculated for two distinctive zones: for the depths $0<z<z^{\mathrm{y}}$, both elastic and plastic deformations develop; for the depths $z>z^{\mathrm{y}}$, only an elastic deformation occurs. The total vertical strain can be obtained as a combination 
of elastic and elasto-plastic deformations as follows (Pulko et al. 2011)

$$
\varepsilon_{z}(z)=\left\{\begin{array}{c}
\varepsilon_{z}^{\mathrm{y}}(z)+\varepsilon_{z}^{\mathrm{p}}(z)=\frac{C_{4} \gamma_{\mathrm{s}} z}{E_{\mathrm{oed}}} \beta^{\mathrm{el}}+\frac{q_{\mathrm{A}}-C_{4} \gamma_{\mathrm{s}} z}{E_{\mathrm{oed}}} \beta^{\mathrm{p}} \\
\text { for } 0<z<z^{\mathrm{y}} \\
\varepsilon_{z}^{\mathrm{el}}=\frac{q_{\mathrm{A}}}{E_{\mathrm{oed}}} \beta^{\mathrm{el}} \text { for } z>z^{\mathrm{y}}
\end{array}\right.
$$

where $\beta^{\text {el }}=E_{\text {oed }} /\left[\left(\lambda_{\mathrm{c}}+2 G_{\mathrm{c}}\right) A_{\mathrm{r}}+\left(\lambda_{\mathrm{s}}+2 G_{\mathrm{s}}\right)\left(1-A_{\mathrm{r}}\right)-2 A_{\mathrm{r}}\left(\lambda_{\mathrm{c}}-\lambda_{\mathrm{s}}\right) F\right]$, $\beta^{\mathrm{p}}=\left[2 D+E_{\mathrm{oed}}\left(C_{2}+T\right)\right] / C_{5}, \quad E_{\mathrm{oed}}$ is the oedometer modulus (also referred to as constrained modulus) of the soil, $\lambda_{\mathrm{s}}, G_{\mathrm{s}}$ and $\lambda_{\mathrm{c}}, G_{\mathrm{c}}$ are Lamé's parameters of the soil and the column respectively, $A_{\mathrm{r}}$ is the replacement ratio of the column area to the total influence area, $T$ is a dimensionless stiffness of the encasement defined as $T=J /$ $\left(E_{\text {oed }} r_{\mathrm{c}}\right)$, where $J$ is the stiffness of the encasement, and $F$, $D, C_{2}$ and $C_{5}$ are all constants and can be found in the paper by Pulko et al. (2011).

The total vertical deformation (i.e. settlement) can be calculated with the integration of vertical strains $\varepsilon_{z}(z)$ along the depth of the column. The input parameters used for the analytical calculation were the same as those used for the model tests and shown in Table 6. It is worth noting that the yield depth in the present study at the given load of $20.1 \mathrm{kPa}$ was $z^{\mathrm{y}}=3.5 \mathrm{~m}$, which is beyond the length of the stone columns, so plastic deformations developed all over the lengths of the encased stone columns.

Figure 13 shows the comparison between the results of the analytical method and the experimental model tests on geogrid-encased stone columns. Two composite foundations with GESC3D and GESC4D were selected for this analysis because they had the encasement length equal to or greater than the effective length. The calculated settlements were in close agreement with the test results of the GESC3D and the GESC4D throughout the applied pressure. Larger differences existed in the GESC3D than those in the GESC4D because the GESC3D had shorter encasement length and some lateral deformation might happen in the unreinforced portion of the stone column. As compared with the analytical solution based on the unit cell concept with full encasement of columns (Pulko et al. 2011), the experimental tests on composite foundations with partially encased columns, which allowed lateral deformations of columns and soils and slippage along the column-soil interfaces (geogrid-soil, stone column-geogrid, and stone column-soil if the column is not encased), resulted in larger settlements, especially at higher vertical pressures. Furthermore, the analytical solution neglected possible plastic and creep deformations of the geosynthetic.

\section{CONCLUSIONS}

In the present study, laboratory model tests were performed on ordinary stone columns (OSC) and geogrid-encased stone columns (GESC) with different encasement lengths to investigate vertical and lateral deformations of the columns and the effect of geogrid encasement. The following conclusions were drawn.
Table 6. Input parameters for calculations

\begin{tabular}{|l|l|}
\hline Parameters & Value \\
\hline Tensile stiffness of the encasement & $680 \mathrm{kN} / \mathrm{m}$ \\
Oedometer modulus of the soil & $300 \mathrm{kPa}$ \\
Young's modulus of the column & $15 \mathrm{MPa}$ \\
Poisson's ratio of the soil and column & 0.2 \\
Dilation angle of the column & $15^{\circ}$ \\
\hline
\end{tabular}

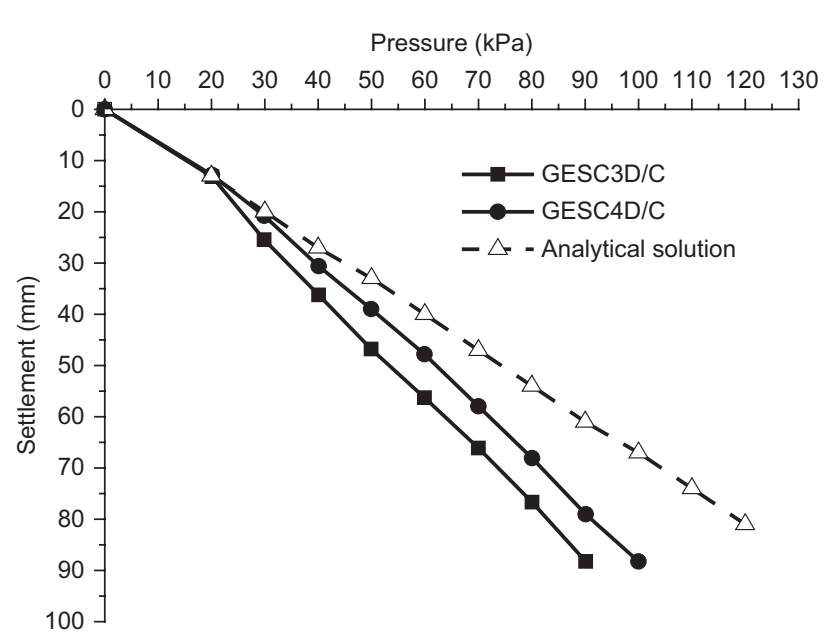

Figure 13. Comparison between the results of the analytical method and the experimental model tests

(1) GESCs were installed in the clay beds with different moisture contents corresponding to different undrained shear strengths in order to examine the behaviour and effectiveness of GESCs for soft ground improvement. The ultimate bearing capacity of the soil was greatly increased by the GESC, especially in the very soft soil $\left(c_{\mathrm{u}}=3.4 \mathrm{kPa}\right)$.

(2) With an increase of the encasement length, the bearing capacity and stiffness of the stone columns increased. The effective length of encasement was three times the diameter of the stone columns based on the consideration of the performance.

(3) The lateral deformation of the stone column decreased due to the additional confining stresses provided by the geogrid encasement. The location of bulging failure of the stone columns changed with the encasement length.

(4) The hoop strains in the encasement sleeve were not constant during loading and varied with the settlement. The pattern of hoop stresses generated in the geogrid encasement closely follows that of the bulging deformation of the stone column.

(5) The stress concentration ratio for the GESC was higher than that for the OSC. The stress reduction ratio from the top to the bottom of the column decreased during staged loading (always less than 1). This result indicates the existence of the shear stresses along the column-soil interface.

(6) As compared with the analytical solution based on the unit cell concept with full encasement of columns, the experimental tests on composite foundations with partially encased columns, which allowed lateral deformations of columns and soils and slippage 
along the column-soil interfaces (geogrid-soil, stone column-geogrid, and stone colum-n-soil if the column is not encased), resulted in larger settlements, especially at higher vertical pressures.

\section{ACKNOWLEDGEMENTS}

This research was funded through the National Natural Science Foundation of China (NSFC No. 51208191) and partially supported by the China Scholarship Council (No. 201406130006). The authors are grateful to the editor and anonymous reviewers for their constructive reviews and suggestions for improving the presentation of this paper.

\section{NOTATION}

Basic SI units are given in parentheses.

\begin{tabular}{|c|c|}
\hline$A_{\mathrm{r}}$ & area replacement ratio (dimensior \\
\hline$c_{\mathrm{u}}$ & undrained shear strength of the soil $(\mathrm{Pa})$ \\
\hline$D$ & diameter of the stone columns (m) \\
\hline$d$ & diameter of the loading plate (m) \\
\hline$d_{\mathrm{c}}$ & depth factor (dimensionless) \\
\hline & oedometer modulus $(\mathrm{Pa})$ \\
\hline$E_{\mathrm{s}}$ & $2 \%$ secant modulus of the geogrid encasement $(\mathrm{N} / \mathrm{m})$ \\
\hline$e$ & $\begin{array}{l}\text { error between the measured and calculated bearing } \\
\text { capacity (dimensionless) }\end{array}$ \\
\hline$F$ & hoop force generated by the encasement sleeve $(\mathrm{N} / \mathrm{m})$ \\
\hline$J$ & tensile stiffness of the encasement $(\mathrm{N} / \mathrm{m})$ \\
\hline$N_{\mathrm{c}}$ & $\begin{array}{l}\text { correction coefficient for bearing capacity } \\
\text { (dimensionless) }\end{array}$ \\
\hline$q_{\mathrm{A}}$ & applied vertical load $(\mathrm{Pa})$ \\
\hline$q_{\mathrm{c}}$ & bearing capacity of the single column $(\mathrm{Pa})$ \\
\hline$q_{\mathrm{s}}$ & bearing capacity of the soil $(\mathrm{Pa})$ \\
\hline$q_{\mathrm{u}}$ & acity $(\mathrm{Pa})$ \\
\hline$q_{\mathrm{u}, \mathrm{c}}$ & $\begin{array}{l}\text { calculated bearing capacity for the composite } \\
\text { foundation }(\mathrm{Pa})\end{array}$ \\
\hline & $\begin{array}{l}\text { measured bearing capacity for the composite } \\
\text { foundation }(\mathrm{Pa})\end{array}$ \\
\hline$r_{\mathrm{c}}$ & radius of the stone column $(\mathrm{m})$ \\
\hline$r_{\mathrm{e}}$ & radius of the loading plate $(\mathrm{m})$ \\
\hline$s_{\mathrm{c}}$ & shape factor (dime \\
\hline$T$ & $\begin{array}{l}\text { dimensionless stiffness of the encasement } \\
\text { (dimensionless) }\end{array}$ \\
\hline$z^{\mathrm{y}}$ & yield depth in the stone column (m) \\
\hline$\gamma_{\mathrm{s}}$ & soil unit weight $\left(\mathrm{N} / \mathrm{m}^{3}\right)$ \\
\hline$\delta_{\varphi}$ & $\begin{array}{l}\text { circumferential displacement of the stone } \\
\text { columns (m) }\end{array}$ \\
\hline$\varepsilon_{\mathrm{r}}$ & radial strain of the stone columns (dimensionless) \\
\hline$\varepsilon_{\varphi}$ & $\begin{array}{l}\text { hoop strain of the geogrid encasement } \\
\text { (dimensionless) }\end{array}$ \\
\hline$\sigma_{r}$ & $\begin{array}{l}\text { radial confining stress provided by the } \\
\text { encasement }(\mathrm{Pa})\end{array}$ \\
\hline & pressure on the column at the ground su \\
\hline & an value of earth pre \\
\hline
\end{tabular}

\section{REFERENCES}

Barksdale, R. D. \& Bachus, R. C. (1983). Design and construction of stone column, Report No. FHWA/RD-83/026. National Technical Information Service, Springfield, VA, USA.

Black, J., Sivakumar, V. \& McKinley, J. D. (2007). Performance of clay samples reinforced with vertical granular columns. Canadian Geotechnical Journal, 44, No. 1, 89-95.

Castro, J. \& Sagaseta, C. (2011). Deformation and consolidation around encased stone columns. Geotextiles and Geomembranes, 29, No. 3, 268-276.

Ghazavi, M. \& Afshar, J. (2013). Bearing capacity of geosynthetic encased stone columns. Geotextiles and Geomembranes, 38, No. 1, 26-36.

Gniel, J. \& Bouazza, A. (2009). Improvement of soft soils using geogrid encased stone columns. Geotextiles and Geomembranes, 27, No. 3 , 167-175.

Gniel, J. \& Bouazza, A. (2010). Construction of geogrid encased stone columns: a new proposal based on laboratory testing. Geotextiles and Geomembranes, 28, No. 1, 108-118.

Han, J. (2015). Principles and Practice of Ground Improvement, Wiley, Hoboken, NJ, USA.

Han, J. \& Ye, S. L. (2001). A simplified method for consolidation rate of stone column reinforced foundations. Journal of Geotechnical and Geoenvironmental Engineering, 127, No. 7, 597-603.

Han, J. \& Ye, S. L. (2002). A theoretical solution for the rate of consolidation of a stone column reinforced foundation accounting for smear and well resistance. International Journal of Geomechanics, 2, No. 2, 135-151.

Hughes, J. M. O. \& Withers, N. J. (1974). Reinforcing of soft cohesive soils with stone columns. Ground Engineering, 7, No. 3, 42-49.

Hunan University (2008). Hoop displacement gauge, Chinese patent number: ZL 200810143670.3.

Murugesan, M. \& Rajagopal, K. (2006). Geosynthetic-encased stone columns: numerical evaluation. Geotextiles and Geomembranes, 24, No. 6, 349-358.

Murugesan, M. \& Rajagopal, K. (2007). Model tests on geosynthetic-encased stone columns. Geosynthetics International, 14, No. 6, 346-354.

Murugesan, M. \& Rajagopal, K. (2010). Studies on the behaviour of single and group of geosynthetic encased stone columns. Journal of Geotechnical and Geoenvironmental Engineering, 136, No. 1, 129-139.

Priebe, H. J. (1995). The design of vibro replacement. Ground Engineering, 28, No. 10, 31-37.

Pulko, B., Majes, B. \& Logar, J. (2011). Geosynthetic-encased stone columns: analytical calculation model. Geotextiles and Geomembranes, 29, No. 1, 29-39.

Raithel, M. \& Kempfert, H. G. (2000). Calculation models for dam foundation with geotextile coated sand columns. Proceedings of the International Conference on Geotechnical and Geological Engineering, GeoEng 2000, Melbourne, Australia.

Tognon, A. R., Rowe, R. K. \& Brachman, R. W. I. (1999). Evaluation of side friction for a buried pipe testing facility. Geotextiles and Geomembranes, 17, No. 4, 193-212.

Van Impe, W. F. (1989). Soil Improvement Techniques and their Evolution, Balkema, Rotterdam, the Netherlands, pp. 63-66.

Vesic, A. S. (1973). Analysis of ultimate loads of shallow foundations. ASCE Journal of the Soil Mechanics and Foundation Division, 99, No. SM1, 45-73.

Wu, C. S., Hong, Y. S. \& Lin, H. C. (2009). Axial stress-strain relation of encapsulated granular column. Computers and Geotechnics, 36, No. 1-2, 226-240.

Yoo, C. \& Lee, D. (2012). Performance of geogrid-encased stone columns in soft ground: full-scale load tests. Geosynthetics International, 19, No. 6, 480-490.

The Editor welcomes discussion on all papers published in Geosynthetics International. Please email your contribution to discussion@geosynthetics-international.com by 15 October 2016. 